\title{
Studies on Some Enzymes of Alginic Acid Biosynthesis in Azotobacter vinelandii Grown in Continuous Culture
}

\author{
By NIGEL J. HORAN, ${ }^{\dagger}$ TREVOR R. JARMAN ${ }^{2} \ddagger$ \\ AND EDWIN A. DAWES ${ }^{*}$ \\ ${ }^{1}$ Department of Biochemistry, University of Hull, Hull HU6 7RX, U.K. \\ ${ }^{2}$ Tate \& Lyle Ltd, Group Research and Development, Philip Lyle Memorial Research \\ Laboratory, P.O. Box 68, Reading RG6 2BX, U.K.
}

(Received 18 February 1983)

\begin{abstract}
When a mutant of Azotobacter vinelandii was grown in continuous culture the amount of exocellular polysaccharide produced was dependent on both the dissolved oxygen tension (d.o.t.) and the carbon source: sucrose supported alginate synthesis in phosphate-limited medium whereas sorbitol did not. Changes in the specific activities of two of the key enzymes of alginate biosynthesis (phosphomannose isomerase and GDPmannose pyrophosphorylase), measured in extracts of cells grown with sucrose under a range of d.o.t. values, were reflected by the observed changes in alginate production; the activity of GDPmannose dehydrogenase was unchanged. A similar correlation between the specific activities of these enzymes and the rate of alginate production was observed during a transition from sorbitol to sucrose as the sole carbon source, but in this experiment the activity of GDPmannose dehydrogenase also increased with increasing alginate production. After prolonged continuous cultivation on sucrose the mutant gradually lost the ability to produce alginate. The key enzymes of alginate biosynthesis could not be detected in extracts of this non-alginate-producing strain, which had also lost the ability to encyst. These results support the suggestions that alginate formation is controlled by derepression of key biosynthetic enzymes and that alginate plays an important role in encystment.
\end{abstract}

\section{INTRODUCTION}

The production of microbial exopolysaccharides has been identified as a potential growth area for the fermentation industry (Sutherland \& Ellwood, 1979). These compounds have the capacity for altering the rheological properties of aqueous solutions, either by gelation or alteration of flow characteristics, properties that are in great demand in the food and textile industries and with a potentially large market in the oil industry.

Alginic acid is one such exopolysaccharide which has been studied with a view to commercial exploitation. Alginate production by a mutant of Azotobacter vinelandii in continuous culture was shown to be dependent on the inorganic phosphate concentration (Deavin et al., 1977). Horan et al. (1981) demonstrated that alginate formation in batch cultures of $A$. vinelandii was also dependent on the carbon source and that the rate of alginate biosynthesis was controlled by derepression of the key biosynthetic enzymes, namely phosphomannose isomerase, GDPmannose pyrophosphorylase and GDPmannose dehydrogenase.

The site of synthesis of exopolysaccharides, lipopolysaccharides and peptidoglycan is the cell membrane; synthesis of these components occurs simultaneously and often shares common

† Present address: Department of Civil Engineering, University of Leeds, Leeds LS2 9JT, U.K.

$\ddagger$ Present address: Patscentre International, Melbourn, Near Royston, Herts SG8 6DP, U.K.

Abbreviation: d.o.t., dissolved oxygen tension. 
precursors and enzymes (Sutherland, 1977). Thus the mechanism of control of exopolysaccharide biosynthesis is likely to be complex. We report further studies on the enzymic basis for control of alginate biosynthesis using both mucoid and non-mucoid $\boldsymbol{A}$. vinelandii grown in continuous culture.

\section{METHODS}

Maintenance and growth of the organism. The organism, designated SM52B, was a mutant of Azotobacter vinelandii NCIB 9068, isolated by Tate \& Lyle Ltd on the basis of its enhanced alginate-producing ability. It was maintained on a medium of composition $\left(1^{-1}\right)$ : sucrose, $20 \mathrm{~g} ; \mathrm{KH}_{2} \mathrm{PO}_{4}, 8 \mathrm{mg} ; \mathrm{K}_{2} \mathrm{HPO}_{4}, 32 \mathrm{mg} ; \mathrm{MgSO}_{4} .7 \mathrm{H}_{2} \mathrm{O}$, $0.2 \mathrm{~g} ; \mathrm{NaCl}, 0.2 \mathrm{~g} ; \mathrm{CaCl}_{2} .2 \mathrm{H}_{2} \mathrm{O}, 42 \mathrm{mg} ; \mathrm{Na}_{2} \mathrm{MoO}_{4}, 1 \mathrm{mg} ; \mathrm{FeSO}_{4} .7 \mathrm{H}_{2} \mathrm{O}, 3 \mathrm{mg} ; \mathrm{H}_{3} \mathrm{BO}_{4}, 2.9 \mathrm{mg} ; \mathrm{CoSO}_{4} .7 \mathrm{H}_{2} \mathrm{O}$, $1.2 \mathrm{mg} ; \mathrm{CuSO}_{4} .7 \mathrm{H}_{2} \mathrm{O}, 0.1 \mathrm{mg} ; \mathrm{MnCl}_{2} .4 \mathrm{H}_{2} \mathrm{O}, 0.09 \mathrm{mg} ; \mathrm{ZnSO}_{4} .7 \mathrm{H}_{2} \mathrm{O}, 1.2 \mathrm{mg} ; \mathrm{MOPS}, 10.5 \mathrm{~g}$. This was adjusted to $\mathrm{pH} 7.2$ with $\mathrm{NaOH}$. This medium was routinely used for continuous cultivation of the organism (with the omission of MOPS) unless otherwise indicated; it ensures an inorganic phosphate limitation when oxygen is in excess.

Bacterial dry weight determinations. These measurements were performed by pipetting cultures through glassfibre filters as described by Horan et al. (1981).

Alginic acid determination. This was done after precipitating alginate from culture supernatants with propan-2-ol according to the method of Jarman et al. (1978). Identification as alginic acid was confirmed by comparison with commercial standards using IR spectrophotometry (Couperwhite \& McCallum, 1974).

Poly- $\beta$-hydroxybutyrate determination. This was done by a modification of the method of Law \& Slepecky (1961) as described by Carter \& Dawes (1979).

Preparation of bacterial extracts. These were prepared as described by Horan et al. (1981).

Enzyme assays. The enzymes glucokinase (EC 2.7.1.2), fructokinase (EC 2.7.1.4), phosphomannose isomerase (EC 5.3.1.8), GDPmannose pyrophosphorylase (EC 2.7.7.13) and GDPmannose dehydrogenase (EC 1.1.1.132) were assayed using the buffers and assays previously described by Horan $e t$ al. (1981). Alginate lyase (EC 4.2.2.3) was not determined directly; this endo-enzyme cleaves alginate by a $\beta$-elimination yielding an unsaturated sugar end and a 4,5-unsaturated uronic acid end group. A measure of alginate lyase activity may be obtained by determining the amount of 4,5-unsaturated uronic acids in solution by the method of Weissbach \& Hurwitz (1959), using $\beta$-formyl pyruvate as a standard over the range 0 to $20 \mathrm{nmol}$.

Continuous culture apparatus. The vessel was of the 'Porton-type', and had a capacity of 2.51. All apparatus was designed and assembled in the department as described by Carter \& Dawes (1979).

Control of dissolved oxygen tension (d.o.t.). The culture d.o.t. was varied over the range to 0 to $10 \%$ air saturation by varying the partial pressure of oxygen in the gas supplied to the culture, thereby maintaining the oxygen transfer coefficient (Harrison, 1976).

Determination of encystment. Washed cell suspensions were induced to encyst by resuspension in the $\beta$ hydroxybutyrate medium of Lin \& Sadoff (1968). The degree of encystment was determined by placing a drop of the encysting culture on a microscope slide and counting the number of vegetative cells and optically refractile cysts per field by phase-contrast microscopy with a Zeiss photomicroscope.

Chemicals and biochemicals. Analytical grade chemicals were used wherever possible. Non-physiological buffers were obtained from Sigma. Mannose 6-phosphate was purchased as the insoluble barium salt and converted to the sodium salt by addition of a slight molar excess of sodium sulphate. Barium sulphate was removed by centrifuging.

Determination of metabolic quotients. The $\mathrm{CO}_{2}$ content of culture effluent gas was measured with an $\mathrm{IR} \mathrm{CO}_{2}$ analyser (Lira model 300, Mine Safety Appliances Ltd., Glasgow, U.K.) and $\mathrm{O}_{2}$ with a Servomex OA 137 oxygen analyser (Servomex Controls Ltd). Oxygen uptake by the culture was determined as the difference between the concentrations of influent and effluent $\mathrm{O}_{2}$. For the calculation it was assumed that the difference in volume between the gas entering the chemostat and the gas leaving it was negligible. No corrections were made for standard temperature and pressure, which were negligible.

Carbohydrate determination. Carbohydrates were determined as their trimethylsilyl ether derivatives, prepared according to Sweeley et al. (1963), and assayed by GLC using a column of OV-17 on Chrom Q. Fructose and glucose were resolved at a column temperature of $150^{\circ} \mathrm{C}$ as was the internal standard cellobiose; sucrose was resolved at $250{ }^{\circ} \mathrm{C}$ with an internal standard of trehalose. The nitrogen flow rate was $20 \mathrm{ml} \mathrm{min}^{-1}$.

Protein determination. The protein content of culture supernatants was measured by the Lowry method.

\section{RESULTS}

\section{Effects of dissolved oxygen tension}

On increasing the d.o.t. of the culture from 0 to $10 \%$ of air saturation $A$. vinelandii SM52B exhibited the classical response of 'respiratory protection', with a large increase in respiration 
Table 1. Effect of d.o.t. on respiration rate and sucrose utilization of chemostat-grown

\section{A. vinelandii}

The organism was grown at a dilution rate of $0.1 \mathrm{~h}^{-1}, \mathrm{pH} 7.2$ and $30^{\circ} \mathrm{C}$, with an impeller speed of 1250 r.p.m. At a d.o.t. value of zero the culture was oxygen limited; above this value it was phosphate limited.

$\begin{array}{ccc}\begin{array}{c}\text { d.o.t. } \\ (\%)\end{array} & \begin{array}{c}q_{\mathrm{O}_{2}} \\ {\left[\mathrm{mmol} \mathrm{h}^{-1}\right.}\end{array} & \begin{array}{c}q_{\mathrm{CO}_{2}} \\ \left.(\mathrm{~g} \mathrm{dry} \mathrm{wt})^{-1}\right]\end{array} \\ 0 & 35 & 20 \\ 1 & 40 & 27 \\ 2 \cdot 5 & 43 & 35 \\ 5 \cdot 0 & 48 & 46 \\ 8 \cdot 0 & 56 & 52 \\ 10 \cdot 0 & 72 & 60\end{array}$

\begin{tabular}{ccc}
\multicolumn{3}{c}{ Residual carbon $\left(\mathrm{g}^{-1}\right)^{*}$} \\
\hline Sucrose & Fructose & Glucose \\
12.0 & 3.0 & 2.0 \\
12.0 & 3.2 & 2.0 \\
10.0 & 2.6 & 1.8 \\
8.2 & 2.4 & 1.8 \\
6.4 & 1.8 & 1.6 \\
5.1 & 1.5 & 0.9
\end{tabular}

$\begin{gathered}\text { Poly- } \beta \text {-hydroxy- } \\ \text { butyrate }\end{gathered}$
$(\%$ of dry wt)
$32 \cdot 1$
$10 \cdot 3$
$8 \cdot 3$
$5 \cdot 2$
$4 \cdot 1$
$2 \cdot 0$

* The sole source of supplied carbon was sucrose $\left(20 \mathrm{~g} \mathrm{l}^{-1}\right)$. Analysis of culture supernatants by GLC also revealed the presence of fructose and glucose.

Table 2. Effect of d.o.t. on the specific activities of enzymes involved in alginate biosynthesis by

\section{A. vinelandii}

Growth conditions were as described in Table 1. Results represent the average of two experiments in which activity did not differ by more than $10 \%$.

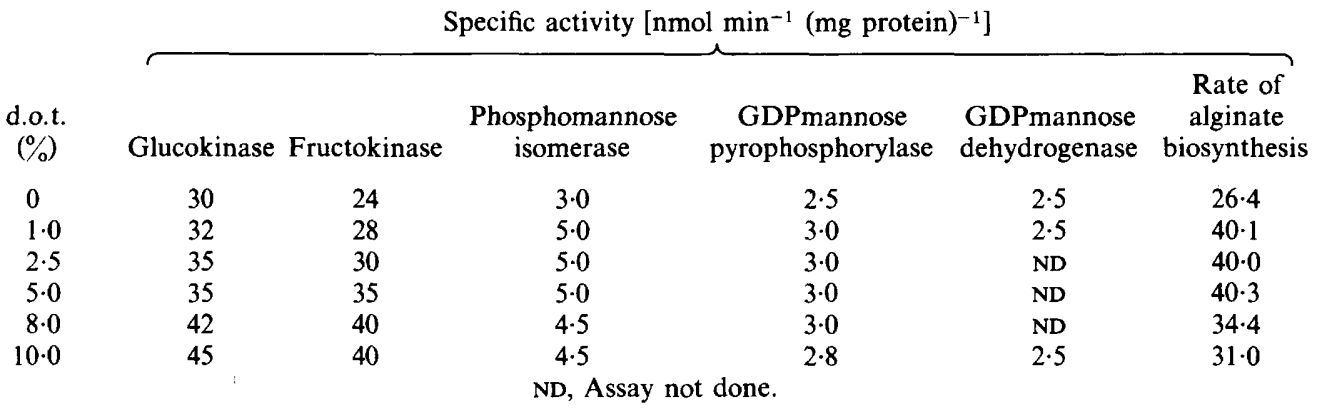

rate and poly- $\beta$-hydroxybutyrate mobilization and increased oxidation of the carbon source (Table 1).

The rate of alginate biosynthesis was also affected by d.o.t. (Table 2), increasing to a plateau between 1 and $5 \%$ d.o.t. and then decreasing at higher d.o.t. values. The activities of two of the key enzymes of alginate biosynthesis, phosphomannose isomerase and GDPmannose pyrophosphorylase, showed concomitant changes whereas GDPmannose dehydrogenase activity was unaffected. Glucokinase and fructokinase activities both increased by up to $60 \%$ as the d.o.t. increased, presumably leading to the observed increase in rate of substrate utilization.

\section{Growth on sorbitol}

We observed previously that during batch growth with sorbitol as the sole source of carbon, alginic acid was not produced by $\boldsymbol{A}$. vinelandii SM52B and the key enzymes of alginate biosynthesis were not detected in cell extracts (Horan et al., 1981). For this reason the effect on alginate biosynthesis of a transition from sorbitol to sucrose as the sole carbon source was determined. The organism grew well on sorbitol in phosphate-limited continuous culture at a dilution rate of $0.1 \mathrm{~h}^{-1}$ with a cell density of $3.5 \mathrm{~g}$ dry wt organism $1^{-1}$ and a poly- $\beta$ hydroxybutyrate content of $25 \%$ of the dry wt (d.o.t. $1 \%$ ). Alginate was not produced and key enzymes of its biosynthesis were not detected in cell extracts. When the medium was changed to a similar one containing sucrose instead of sorbitol, alginate appeared in the culture supernatant after $16 \mathrm{~h}$ and alginate production characteristic of growth on sucrose was attained after $45 \mathrm{~h}$. Again appearance of the key enzymes of alginate biosynthesis was observed concomitantly with production of alginate by the organism (Table 3 ). 
Table 3. Effect of changing the carbon source from sorbitol to sucrose on the rate of alginate biosynthesis and the specific activities of the enzymes involved

The organism was grown in a chemostat under inorganic phosphate limitation at a dilution rate of $0 \cdot 1 \mathrm{~h}^{-1}, \mathrm{pH} 7.2$ and $30^{\circ} \mathrm{C}$, with an impeller speed of 1250 r.p.m. (d.o.t. $1 \%$ ). At zero time the medium was changed from $20 \mathrm{~g}$ sorbitol $\mathrm{1}^{-1}$ to $20 \mathrm{~g}$ sucrose $\mathrm{l}^{-1}$. The results represent the average of two independent samples, taken at a $72 \mathrm{~h}$ interval, which did not differ by more than $10 \%$. Duplicate assays on the same extract differed by not more than $5 \%$.

$\begin{array}{ccccc}\begin{array}{c}\text { Time from } \\ \text { start of } \\ \begin{array}{c}\text { transition } \\ \text { (h) }\end{array}\end{array} & \begin{array}{c}\text { Phosphomannose } \\ \text { isomerase }\end{array} & \begin{array}{c}\text { GDPmannose } \\ \text { pyrophosphorylase }\end{array} & \begin{array}{c}\text { GDPmannose } \\ \text { dehydrogenase }\end{array} & \begin{array}{c}\text { Rate of } \\ \text { alginate } \\ \text { biosynthesis }\end{array} \\ 0 & 0 & 0 & 0 & 0 \\ 16 & 2 \cdot 0 & 1 \cdot 0 & \text { ND } & 1 \cdot 0 \\ 45 & 3 \cdot 5 & 2 \cdot 4 & \text { ND } & 8 \cdot 8 \\ 60 & 4 \cdot 0 & 2 \cdot 4 & \text { ND } & 9 \cdot 4 \\ 85 & \text { ND } & \text { ND } & 2 \cdot 0 & 9 \cdot 4\end{array}$

ND, Assay not done.

Table 4. Protein content and the activity of alginate lyase in culture supernatants of $A$. vinelandii

\begin{tabular}{lcc} 
Growth method & $\begin{array}{c}\text { Protein content } \\
\left(\mu \mathrm{g} \mathrm{ml}^{-1}\right)\end{array}$ & $\begin{array}{c}4,5-\text { Unsaturated } \\
\text { uronic acid content } \\
\left.(\mathrm{nmol} \mathrm{ml})^{-1}\right)\end{array}$ \\
Batch culture & & \\
$38 \mathrm{~h}$ & 0 & $0 \cdot 7$ \\
$42 \mathrm{~h}$ & 0 & $0 \cdot 5$ \\
$63 \mathrm{~h}$ & 18 & $0 \cdot 7$ \\
$89 \mathrm{~h}$ & 17 & $0 \cdot 7$ \\
Continuous culture & & \\
d.o.t. $=0 \%$ & 90 & $8 \cdot 5$ \\
d.o.t. $=10 \%$ & 93 & $9 \cdot 5$ \\
\multicolumn{2}{c}{ Grown as described in Table 1.}
\end{tabular}

Activity of alginate lyase during continuous culture

Because of the low yields of alginate obtained during continuous cultivation as compared with those characteristic of batch culture $[1 \mathrm{mg} \text { and } 6 \mathrm{mg} \text { alginate (mg dry wt organism })^{-1}$ respectively], the activity of alginate lyase was assayed in the suspending fluid (Table 4). Both the activity of this enzyme and the amount of protein found in culture supernatants were considerably higher during continuous cultivation compared with batch cultivation.

\section{Isolation of a non-alginate-producing mutant of A. vinelandii}

Growth of $A$. vinelandii SM52B on sucrose in continuous culture for longer than $300 \mathrm{~h}$ resulted in a gradual loss of alginate-producing ability, and the appearance of small non-viscous colonies was observed on agar plates during routine purity checks. Within $72 \mathrm{~h}$ of the first appearance of these small colonies, the ability to produce alginate was completely lost and no characteristic large viscous colonies were observed on agar plates. Alginate-producing ability appeared to be the only major characteristic to change in continuous culture; respiration rate, protein and poly- $\beta$-hydroxybutyrate content all remained constant. Another feature observed during the characterization of this mutant was the loss of its ability to form cysts. If washed suspensions of strain SM52B were resuspended in encystment medium, within $60 \mathrm{~h} 96 \%$ of the cells were present as optically refractile cysts. The non-alginate-producing mutant yielded only $0 \cdot 1 \%$ cysts after $84 \mathrm{~h}$. Cell extracts prepared from this mutant grown in continuous culture lacked the key enzymes of alginate biosynthesis although the activities of glucokinase and fructokinase were unchanged. 


\section{DISCUSSION}

Alginate production by the mutant SM52B showed similar characteristics to those of the parent A. vinelandii strain (Jarman et al., 1978). In continuous culture the rate of alginate synthesis was lower under oxygen limitation and was also dependent on d.o.t. under phosphate limitation. The loss of alginate-producing ability on prolonged'continuous culture was more pronounced in the mutant, which displayed a rapid decline after $300 \mathrm{~h}$ cultivation whereas the parent strain has been cultivated for more than $1000 \mathrm{~h}$ without significant decline in alginate synthesis (T. R. Jarman, unpublished observations). Such loss of alginate-producing ability during continuous cultivation is not unique to this mutant organism. Mian et al. (1978) grew mucoid Pseudomonas aeruginosa for $112 \mathrm{~h}$ in continuous culture, after which time the culture contained $45 \%$ non-mucoid organisms; similarly many mucoid clinical isolates of $P$. aeruginosa become non-mucoid when grown on synthetic media (Govan et al., 1979).

The correlation between the activities of the key enzymes of alginate biosynthesis and concentrations of alginate in the growth medium provides further evidence that control is exerted by repression and derepression. A genetic basis for such control has been sought by Fyfe $\&$ Govan (1980) to explain the appearance of mucoid and non-mucoid strains of $P$. aeruginosa. The ability to produce alginate is transferable between strains of this organism by conjugation. The results of mating experiments with mucoid and non-mucoid strains suggested that control of alginate production involves at least one chromosomal locus although the number of genes involved in control could not be determined since a closely-linked marker had not been found. The genetic basis for the control of colanic acid synthesis in Escherichia coli $\mathrm{K} 12$ has been reviewed by Markovitz (1977). Non-mucoid strains of this organism could be induced to become mucoid when grown in the presence of $p$-fluorophenylalanine and it was inferred that all strains possessed the necessary genotype for colanic acid synthesis but the majority had this ability repressed by a regulatory gene rendered inactive by $p$-fluorophenylalanine. Sutherland (1977) has speculated that polysaccharide production in other genera may be controlled by similar regulatory genes; a search for a vector carrying the genes controlling alginate biosynthesis in $A$. vinelandii might prove fruitful in elucidating the precise mechanism by which the activities of the enzymes of alginate biosynthesis are repressed and derepressed.

The loss of ability to encyst shown by the non-polysaccharide-producing isolate of $A$. vinelandii provides supporting evidence for a structural role for alginic acid in encystment (Page \& Sadoff, 1975). These authors have found mannuronic and guluronic acid residues in both cyst exine and intine layers and in abortive encystment slime. The ratio of polymannuronate to polyguluronate in $A$. vinelandii is mediated by a $\mathrm{Ca}^{2+}$-dependent polymannuronate $\mathrm{C}-5$ epimerase (Haug \& Larsen, 1971) and a non-encysting mutant isolated by Page \& Sadoff (1975) lacked this enzyme. Unfortunately, these authors did not attempt to assay other enzymes of alginate biosynthesis.

Continuous cultivation of bacteria with high impeller speeds may result in damage to the integrity of the cell membrane by shear (Finn \& Fiechter, 1979). The observation of high unsaturated uronic-acid levels and the presence of glucose and fructose in culture supernatants of sucrose-grown $\boldsymbol{A}$. vinelandii suggest that this organism possesses a fragile cell membrane which is damaged during continuous cultivation, allowing leakage of intracellular proteins including invertase and alginate lyase. The action of alginate lyase yields a product unsuitable for commercial application and thus this organism appears a poor choice for commercial exploitation, unless alginate lyase activity can be diminished through mutation or inhibition, or its leakage from the cells suppressed.

We are grateful to the Science and Engineering Research Council for the award of a CASE studentship to N. J.H. and to Tate \& Lyle Ltd, for permission to publish this research.

\section{REFERENCES}

CARTER, I. S. \& Dawes E. A. (1979). Effect of oxygen concentration and growth rate on glucose metabolism, poly- $\beta$-hydroxybutyrate biosynthesis and respiration of Azotobacter beijerinckii. Journal of General Microbiology 110, 393-400.
Couperwhite, I. \& McCallum, M. F. (1974). The influence of EDTA on the composition of alginate synthesized by Azotobacter vinelandii. Archives of Microbiology 97, 73-80. 
Deavin, L., JaRman, T. R., Lawson, C. J., RigheLATO, R. C. \& SLOCOMBE, S. (1977). The production of alginic acid by Azotobacter vinelandii in batch and continuous culture. In Extracellular Microbial Polysaccharides, pp. 14-26. Edited by P. A. Sandford \& A. Laskin. Washington: American Chemical Society.

FINN, R. K. \& FiechteR, A. (1979). The influence of microbial physiology on reactor design. Symposia of the Society for General Microbiology 29, 83-105.

Fyfe, J. A. M. \& Govan, J. R. W. (1980). Alginate synthesis in mucoid Pseudomonas aeruginosa: a chromosomal locus involved in control. Journal of General Microbiology 111, 443-450.

Govan, J. R. W., Fyfe, J. A. M. \& McMillan, C. (1979). Instability of mucoid Pseudomonas aeruginosa - fluctuation test and improved stability of the mucoid form in shaken culture. Journal of General Microbiology 110, 229-232.

HARRISON, D. E. F. (1976). The Oxygen Metabolism of Micro-organisms. Shildon: Meadowfield Press.

Haug, A. \& Larsen, B. (1971). Biosynthesis of alginate. II. Polymannuronic acid C-5-epimerase from Azotobacter vinelandii. Carbohydrate Research 32 317-325.

Horan, N. J., Jarman, T. R. \& Dawes, E. A. (1981). Effects of carbon source and inorganic phosphate concentration on the production of alginic acid by a mutant of Azotobacter vinelandii and on the enzymes involved in its biosynthesis. Journal of General Microbiology 127, 185-191.

Jarman, T. R., Deavin, L., Slocombe, S. \& RigheLATO, R. C. (1978). Investigation of the effects of environmental conditions on the rate of exopolysaccharide synthesis in Azotobacter vinelandii. Journal of General Microbiology 107, 59-64.
LAW, J. H. \& SLEPECKY, R. A. (1961). Assay of poly- $\beta$ hydroxybutyric acid. Journal of Bacteriology 82, 3336.

LiN, L. P. \& SADOFF, H. L. (1968). Encystment and polymer production by Azotobacter vinelandii in the presence of $\beta$-hydroxybutyrate. Journal of Bacteriology 95, 2336-2343.

MARKOVITZ, A. (1977). Genetics and regulation of bacterial capsular polysaccharide biosynthesis and radiation sensitivity. In Surface Carbohydrates of the Prokaryotic Cell, pp. 415-482. Edited by I. W. Sutherland. London: Academic Press.

Mian, F. A., Jarman, T. R. \& Righelato, R. C. (1978). Biosynthesis of exopolysaccharide by Pseudomonas aeruginosa. Journal of Bacteriology 134, 418422.

Page, W. J. \& SAdoff, H. L. (1975). Relationship between calcium and uronic acids in the encystment of Azotobacter vinelandii. Journal of Bacteriology 122 , 145-151.

SUTHERLAND, I. W. (1977). Microbial exopolysaccharide synthesis. In Extracellular Microbial Polysaccharides, pp. 40-57. Edited by P. A. Sandford \& A. Laskin. Washington: American Chemical Society.

Sutherland, I. W. \& Ellwood, D. C. (1979). Microbial exopolysaccharides. Symposia of the Society for General Microbiology 29, 107-150.

Sweeley, C. C., Bentley, R., Makita, M. \& Wells, W. W. (1963). Gas-liquid chromatography of trimethylsilyl derivatives of sugars and related substances. Journal of American Chemical Society 85, 2497-2507.

Weissbach, A. \& Hurwitz, J. (1959). The formation of 2-keto-2-deoxyheptonic acid in extracts of Escherichia coli B. Journal of Biological Chemistry 234, 705709. 